\title{
Pretreating Stored Human Urine for Solar Evaporation by Low-Technology Ammonia Stripping
}

\author{
Holger Gulyas*, Shidong Zhang, Ralf Otterpohl \\ Hamburg University of Technology, Institute of Wastewater Management and Water Protection, Hamburg, \\ Germany \\ Email: holli@tuhh.de
}

Received 8 July 2014; revised 29 July 2014; accepted 13 August 2014

Copyright (C) 2014 by authors and Scientific Research Publishing Inc.

This work is licensed under the Creative Commons Attribution International License (CC BY). http://creativecommons.org/licenses/by/4.0/

(c) (i) Open Access

\section{Abstract}

In order to avoid the loss of ammonia during solar drying of stored urine, low-tech stripping is suggested as a pretreatment process for ammonia recovery. The mass transfer of ammonia from stored urine with an initial pH of about 9 was tested in a simple closed vessel operated at $72^{\circ} \mathrm{C}$, $74^{\circ} \mathrm{C}$ and $85^{\circ} \mathrm{C}$. The specific urine/gas interface was $16.97 \mathrm{~m}^{-1}$. For ammonia absorption, a beaker with sulfuric acid was positioned in the gas phase of the container. After keeping the stored urine for $73 \mathrm{~h}$ at $85^{\circ} \mathrm{C}$, the concentration of free ammonia $\left(\mathrm{NH}_{3}\right)$ was reduced by more than $99 \%$, and the $\mathrm{pH}$ of the stored urine decreased to 6.4 due to ammonia volatilization. Total ammonia $\left(\mathrm{NH}_{3}+\right.$ $\mathrm{NH}_{4}^{+}$) concentration was reduced by only $83 \%$ in the same period. At lower temperatures, the process was slower. Required treatment time can be reduced when specific gas/liquid interface is increased. Because it is known that water can be heated in solar boxes to temperatures above $90^{\circ} \mathrm{C}$, this simple stripping apparatus is feasible to be operated with solar energy in remote areas with suitable climatic conditions where no electric power is available. As the area demand for solar "low-tech stripping" is less than $1 \mathrm{~m}^{2}$ per capita, this process can be looked at as a suitable pretreatment of stored urine prior to solar evaporation.

\section{Keywords}

Ammonia Recovery, Ecological Sanitation, Low-Technology Stripping, Mass Transfer, Urine Drying

\footnotetext{
*Corresponding author.
} 


\section{Introduction}

Human urine separately collected in urine-diverting toilets or waterless urinals has been demonstrated to be a valuable fertilizer in agriculture [1]-[4] and may contribute to food security especially for poor farmers who cannot afford synthetic fertilizers [5]. A six months storage of urine at $20^{\circ} \mathrm{C}$ is considered to make it a hygienically safe fertilizer for any crop, as there is even virucidal action of the ureolyzed urine due to its elevated $\mathrm{pH}$ of around 9 [6]. Vinnerås et al. [7] have emphasized that the urine should not be diluted, because hygienization during storage was found to depend on ammonia concentration. Below an ammonia concentration of $40 \mathrm{mM}$, pathogenic microorganisms persisted longer irrespective of temperature. Using human urine for fertilization requires separate urine collection, i.e. so-called “ecological sanitation” [5] or "resources-oriented sanitation” systems. For agricultural use, the urine (or yellow water) — consisting mainly of water-has to be transported from the collection sites to the fields by trucks causing considerable energy consumption when this distance is long. Therefore, a feasible concentration process for enrichment of the nutrients and transporting only the concentrate to the fields would help to save energy.

Due to the high salt concentrations in urine, reverse osmosis of yellow water requires high pressures and is likely to be highly energy-consuming. Similarly, electrodialysis is looked at as highly energy-consuming [8]. Nanofiltration was shown to reject phosphate efficiently, while a high proportion of the nutrient ammonia escaped with the permeate [9]. High power consumption has also been estimated for freeze concentration of urine [10]. Another option is struvite precipitation by adding $\mathrm{Mg}^{2+}$ to the stored urine [11]-[13]. Although struvite is a tradable fertilizer and salts and pharmaceuticals are separated from the fertilizing substance, this process bears the disadvantage of losing the nutrient potassium. Moreover, the residing liquid phase has to be disposed of in a suitable way. This is also the case when phosphate is separated from urine by anion exchange [14]. Additionally, zeolite adsorption [15] [16] and stripping [11] [17]-[19] of stored urine have been investigated for ammonia removal and recovery. However, other nutrients remain in the aqueous solution.

Evaporation of urine will enrich all non-volatile materials and is looked at as promising because it can be powered by the sun in solar stills [8] [20]. However, evaporation of stored urine leads to volatilization and loss of ammonia. Therefore, acidification of the urine prior to evaporation e.g. with phosphoric acid was suggested [8] [20]. This causes a high acid consumption because stored urine exhibits high alkalinity due to ureolysis. An alternative is aerobic biological treatment prior to evaporation converting the volatile ammonia to non-volatile compounds [21]. Pronk and Koné [8] proposed to nitrify only about 50\% of the ammonia in order to obtain an aqueous solution containing ammonium nitrate.

Except by acidification or nitrification, urine can be pretreated by stripping for avoiding ammonia losses from stored urine in a subsequent solar evaporation stage. In comparison to municipal wastewater, volume flows of separately collected urine are small. A volume of 1.37 l urine (median value) is discharged per capita and day [22]. Therefore, also a slow stripping process might be acceptable when it can be operated even in remote areas without power supply. A solar "low-tech stripping” process would be well in line with solar stills as a second stage for evaporating the pre-stripped urine in order to concentrate the non-volatile nutrients.

The aim of this study was to investigate the potential of a low-technology mass transfer process for ammonia recovery from stored urine in a closed vessel without aeration or stirring but operated at elevated temperatures $\left(72^{\circ} \mathrm{C}-85^{\circ} \mathrm{C}\right)$ which might also be generated in solar boxes. $\mathrm{NH}_{3}$ was to be absorbed in an acidic solution in equilibrium with the gas phase. In this way, less acid should be consumed than would be by acidification of the stored urine which contains considerable amounts of hydrogen carbonate/carbonate besides $\mathrm{NH}_{3}$.

\section{Materials and Methods}

\subsection{Experimental Setup}

A3-L-glass flat ground flange reaction vessel (inner diameter $14.7 \mathrm{~cm}$ ) covered with a flat ground flange lid with three necks was used as a mass transfer apparatus (Figure 1). The lid was fixed to the vessel with a latch. The container was filled with $1 \mathrm{~L}$ of urine stored for more than 3 months (provided from a public waterless urinal in Hamburg, Germany). A 250-mL beaker (inner diameter $6.5 \mathrm{~cm}$ ) filled with $70 \mathrm{~mL}$ of diluted sulfuric acid (concentrated sulfuric acid diluted 1:3 with deionized water) was placed on a PVC rack inside the vessel. A balloon was connected to one of the necks of the lid allowing for equalization of the inside pressure with atmospheric pressure. The other two necks were supplied with cone screwthread adapters fixed on the necks by means of clamps. Through one of them, a thin plastic sampling tube was introduced into the urine and connected to a 


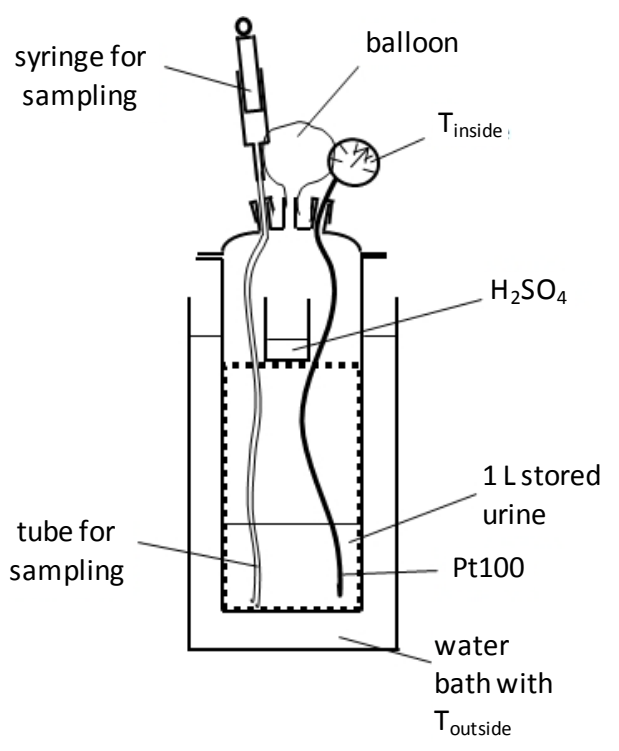

Figure 1. Experimental mass transfer apparatus for investigating ammonia removal from stored urine.

30-mL plastic syringe outside the container. The other cone screwthread adapter was used as a cable conduit for a Pt 100 thermoelement which was placed in the urine. The reaction vessel was placed in the water bath of a thermostate (LaudaEcoline RE 312) and fixed to a stand with a belt.

\subsection{Experimental Procedure and Sampling}

Before each experiment, a new $1 \mathrm{~L}$ batch of stored urine was filled into the mass transfer apparatus which was simply allowed to stand in the water bath for up to $96.5 \mathrm{~h}$ at temperatures adjusted a few ${ }^{\circ} \mathrm{C}$ above the desired urine temperatures which were $72^{\circ} \mathrm{C}, 74^{\circ} \mathrm{C}$ and $85^{\circ} \mathrm{C}$, respectively, in the three experiments. Also the $\mathrm{H}_{2} \mathrm{SO}_{4}$ vessel inside the mass transfer apparatus was filled with fresh sulfuric acid prior to each experimental run. At different times of the experiments, $14 \mathrm{~mL}$ of urine were withdrawn by means of the syringe. Prior to sampling, the urine in the container was mixed by aspirating $20 \mathrm{~mL}$ urine into the syringe and pushing it vigorously back into the container immediately. This was repeated 10 times before the actual sample was withdrawn. After each sampling, the sampling tube was sealed with a Hoffmann type pinchcock until the next sampling. Samples were transferred to 20 -mL welted glasses with snap-on lids immediately after collection.

\subsection{Analyses}

After cooling the samples to room temperature, $\mathrm{pH}$ was determined by means of a $\mathrm{pH}$ probe (WTWSenTix 41) connected to a pH meter (WTW Multi 3401). Total ammonia nitrogen (TAN) concentration (i.e. the sum of $\mathrm{NH}_{4}^{+}-\mathrm{N}$ and $\mathrm{NH}_{3}-\mathrm{N}$ concentrations) in the samples was determined in duplicate. For each determination, $5 \mathrm{~mL}$ of sample were transferred into a steam distillation sample tube. Five $\mathrm{mL}$ of a $32 \% \mathrm{NaOH}$ solution were added and the mixture was subjected to steam distillation in a Büchi Distillation Unit K-350. The distillate was absorbed in a $250 \mathrm{~mL}$ Erlenmeyer flask containing $20 \mathrm{~mL}$ of $0.1 \mathrm{~N}$ sulfuric acid, $40 \mathrm{~mL}$ deionized water and 2 droplets of an ethanolic solution of Tashiro indicator. After steam distillation was accomplished, this solution was titrated with $0.1 \mathrm{~N} \mathrm{NaOH}$ solution until color change of the indicator from violet to greyish tinge occurred.

\section{Results and Discussions}

Figure 2(a) shows the analyzed TAN concentrations (sum of $\mathrm{NH}_{4}^{+}-\mathrm{N}$ and $\mathrm{NH}_{3}-\mathrm{N}$ ) in the stored urine at different times and temperatures. In Figure 2(b), the $\mathrm{pH}$ in the urine samples is shown. Due to mass transfer of $\mathrm{NH}_{3}$ from the stored urine to the gas phase and subsequent absorption into the sulfuric acid, the TAN concentration as well as the $\mathrm{pH}$ in the stored urine was decreasing with time. It can be seen from Figure 2(a) that the mass trans- 
fer was accelerated with increasing temperature. The first experiment at $72^{\circ} \mathrm{C}$ was performed for a too short period. Therefore, the experiment was repeated although at a slightly higher temperature, but for more than 50 h.

The $\ln \left(\mathrm{TAN}_{0} / \mathrm{TAN}\right)$ data plotted over time did not yield a straight line (data not shown) as expected for the desorption of a volatile from a solution, because only the free ammonia nitrogen (FAN), i.e. $\mathrm{NH}_{3}-\mathrm{N}$, was transferred to the gas phase. Therefore, FAN concentrations in the stored urine were calculated from TAN concentrations. For this purpose, the $p K_{a}$ of ammonia had to be calculated. The temperature dependence of $p K_{a}$ for $\mathrm{NH}_{4}{ }^{+} / \mathrm{NH}_{3}$ in pure water, $p K_{a}^{w}$, is given by Equation (1) [23]. T is the absolute temperature.

$$
p K_{a}^{w}=0.09108+\frac{2729.92 K}{T}
$$

Moreover, $p K_{a}$ is affected by ionic strength, I, of the solution as expressed in Equation (2) [24]. The ionic strength of stored urine was estimated to be $0.6 \mathrm{~mol} \cdot \mathrm{L}^{-1}$ according to Siegrist et al. [19]. It has to be pointed out that the dependence of $p K_{a}$ on ionic strength itself is influenced by temperature.

$$
p K_{a}=p K_{a}^{w}+\left[0.1552 \mathrm{~L} \cdot \mathrm{mol}^{-1}-0.0003142 \mathrm{~L} \cdot \mathrm{mol}^{-1} \cdot \mathrm{K}^{-1} \cdot(T-273.2 \mathrm{~K})\right] \cdot I
$$

Of course, the determined $p K_{a}$ values are rather estimates than exact data, because firstly, the ionic strength of the stored urine was estimated and secondly, the temperature range for which Equation (2) was established is between $5^{\circ} \mathrm{C}$ and $40^{\circ} \mathrm{C}$ [24]. Nevertheless, these $p K_{a}$ values were utilized to calculate FAN by means of Equation (3) from TAN concentrations and pH data displayed in Figure 2.

$$
F A N=\frac{1}{1+10^{\left(p K_{a}-p H\right)}} \cdot T A N
$$

The calculated FAN concentrations in the stored urine at different times are shown in Figure 3(a). At the end of the experiments, FAN concentrations were markedly lower than TAN concentrations (compare Figure 3(a) to Figure 2(a)). After 48 hours mass transfer without any agitation or use of stripping gas, the FAN concentration was nearly zero when the temperature was $85^{\circ} \mathrm{C}$. At this time, the $\mathrm{pH}$ in the stored urine has decreased to about 6.5 (Figure 2(b)). It can be assumed that stored urine pretreated by "low-tech stripping" to this extent is feasible for solar distillation without pronounced losses of ammonia.

In a batch stripping system, the decrease of the volatile concentration in the liquid phase, $c_{L}$, with time can be described by Equation (4).

$$
\frac{\mathrm{d} c_{L}}{\mathrm{~d} t}=-K_{L} \cdot a \cdot\left(c_{L}-c_{L}^{*}\right)
$$

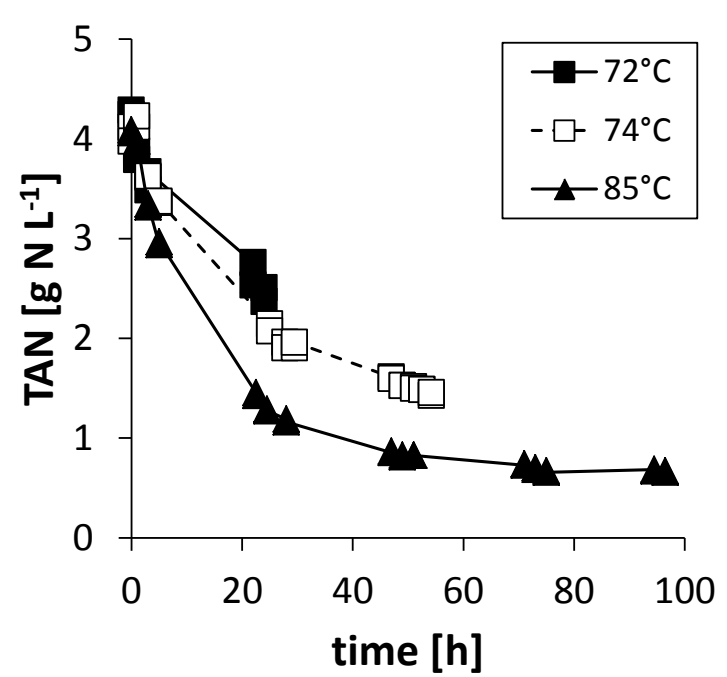

(a)

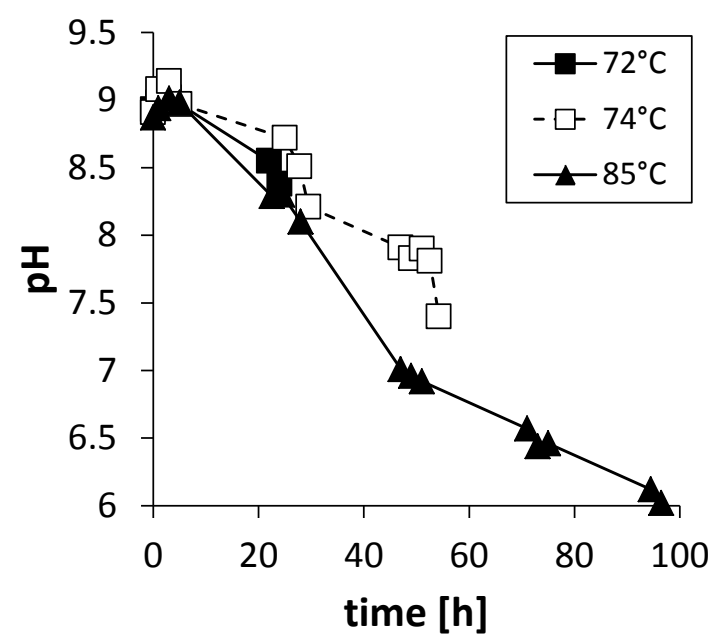

(b)

Figure 2. Total ammonia nitrogen concentration, TAN (a) and pH (b) in stored urine during ammonia mass transfer at the investigated temperatures. 


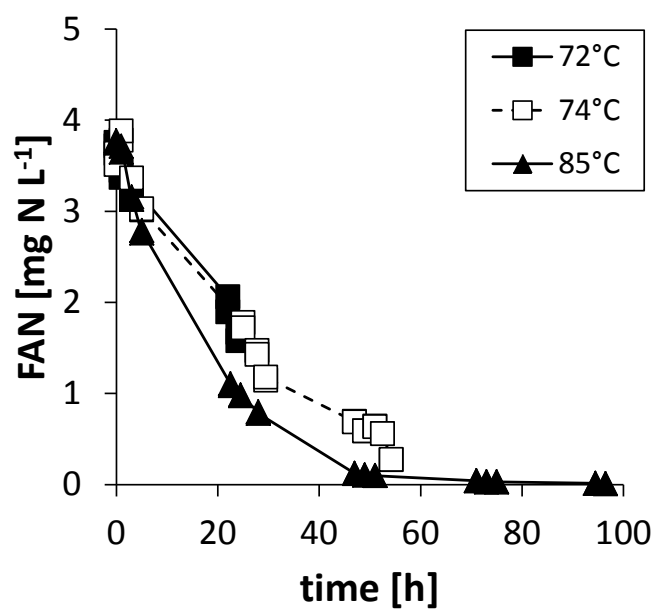

(a)

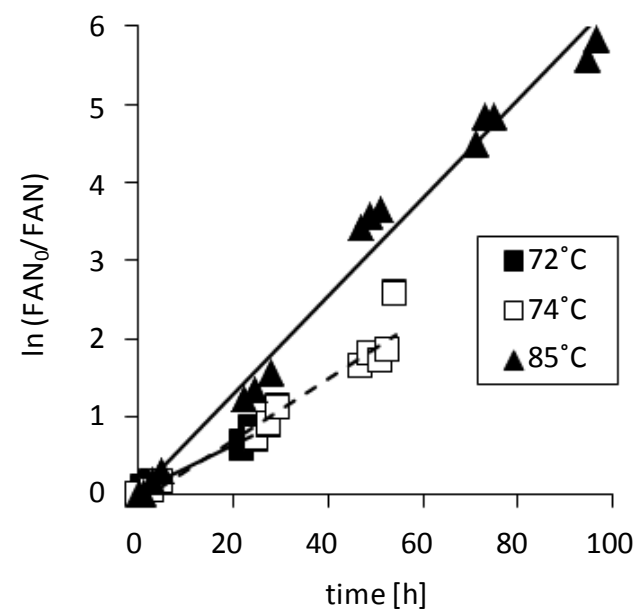

(b)

Figure 3. Free ammonia nitrogen concentration, FAN (a), and natural logarithm of $\mathrm{FAN}_{0} / \mathrm{FAN}$ (b) in stored urine during ammonia mass transfer at the investigated temperatures; for slopes of lines in Figure 3(b) and determination coefficients, $\mathrm{R}^{2}$, see Table 1 .

FAN is represented by $c_{L}$. The constant $K_{L}$ is the overall mass transfer coefficient for $\mathrm{NH}_{3}$ for the liquid phase, and "a" is the specific gas/liquid interface. The equilibrium FAN concentration in the liquid phase the system strives for, is $c_{L}^{*}$. The reaction of $\mathrm{NH}_{3}$ in sulfuric acid is fast and irreversible. So, the rate of mass transfer for the absorption is only limited by the gas phase resistance [17]. Assuming that the sulfuric acid located in the gas phase of the mass transfer apparatus will absorb all $\mathrm{NH}_{3}$ from the gas phase, a target FAN concentration in the liquid phase of zero can be postulated. Therefore, Equation (4) can be simplified as follows:

$$
\frac{\mathrm{d} c_{L}}{\mathrm{~d} t}=-K_{L} \cdot a \cdot c_{L}
$$

After rearrangement, Equation (5) can be integrated yielding Equation (7):

$$
\begin{gathered}
\int_{c_{L 0}}^{c_{L}(t)} \frac{\mathrm{d} c_{L}}{c_{L}}=-K_{L} \cdot a \cdot \int_{0}^{t} \mathrm{~d} t \\
\ln \frac{c_{L 0}}{c_{L}(t)}=K_{L} \cdot a \cdot t
\end{gathered}
$$

Equation (7) corresponds well to the straight lines in Figure 3(b). The slopes represent the volumetric mass transfer coefficients, $K_{L} \cdot a$. They are given for the three investigated temperatures in Table 1 together with the $\mathrm{pK}_{\mathrm{a}}$ values for the $\mathrm{NH}_{4}^{+} / \mathrm{NH}_{3}$ equilibria calculated by Equations (1) and (2). In the investigated simple mass transfer apparatus, the volumetric mass transfer coefficients were rather low even at the tested elevated temperatures. Stripping of ammonia from stored urine by aeration in a counter-current packed column operated at a gas/liquid flow ratio of about 0.1 led to much larger volumetric mass transfer coefficients which were in the range of $1.25 \mathrm{~h}^{-1}$ (at $24^{\circ} \mathrm{C}$ ) to $4.2 \mathrm{~h}^{-1}$ (at $54^{\circ} \mathrm{C}$ ) [18].

Contrasting to aerated strippers or steam strippers, the specific interface, " $a$ ", can be easily determined in the investigated mass transfer apparatus; it is simply the surface of the liquid related to the liquid volume $(0.01697$ $\left.\mathrm{m}^{2} / 0.001 \mathrm{~m}^{3}=16.97 \mathrm{~m}^{-1}\right)$. By means of the specific interface, the overall mass transfer coefficients, $K_{L}$, can be calculated from the volumetric mass transfer coefficients (see Table 1).

It is suggested to integrate closed vessels containing rather shallow layers of stored urine and an acidic absorber into solar boxes which are propagated for solar cooking. It has been reported that within solar boxes sufficiently high temperatures are achieved. In Sudan, water was heated in such a device from $60^{\circ} \mathrm{C}$ at $11: 00$ a.m. to $98^{\circ} \mathrm{C}$ at 12:20 p.m. [25] and in Nigeria from $40^{\circ} \mathrm{C}$ at $11: 45$ a.m. to $98^{\circ} \mathrm{C}$ at $1: 30$ p.m. [26]. Solar boxes can be produced from cheap materials which are available also in poor regions of the world. Once the stored urine is pretreated by "solar stripping" for ammonia recovery, it is suitable for solar evaporation without large losses of ammonia. 
Table 1. Temperature influence on $p K_{a}$ for $\mathrm{NH}_{3} / \mathrm{NH}_{4}^{+}$equilibrium, volumetric mass transfer coefficient and overall mass transfer coefficient for $\mathrm{NH}_{3}$ volatilization in the investigated mass transfer apparatus; $\mathrm{R}^{2}$ : coefficients of determination for graphs in Figure 3(b).

\begin{tabular}{ccccc}
\hline $\begin{array}{c}\text { Temperature } \\
{\left[{ }^{\circ} \mathrm{C}\right]}\end{array}$ & $p K_{a}$ & $\begin{array}{c}K_{L} \cdot a \\
{\left[\mathrm{~h}^{-1}\right]}\end{array}$ & $\begin{array}{c}K_{L} \\
{\left[\mathrm{~m} \cdot \mathrm{h}^{-1}\right]}\end{array}$ & $\mathrm{R}^{2}$ \\
\hline 72 & 8.079 & 0.0306 & 0.0018 & 0.9723 \\
74 & 8.033 & 0.0394 & 0.00232 & 0.953 \\
85 & 7.789 & 0.063 & 0.00371 & 0.9842 \\
\hline
\end{tabular}

Area demand for solar low-tech stripping devices in solar box cookers can be estimated by rearranging Equation (7). Considering that the specific interface is the gas/liquid interface, " $A$ ", related to the liquid volume, $V_{L}$, the rearrangement results in Equation (8). This equation can be used to calculate the surface " $A$ " of the liquid in a non-agitated and non-aerated low-tech stripping device.

$$
A=\frac{V_{L} \cdot \ln \frac{C_{L 0}}{C_{L}(t)}}{K_{L} \cdot t}
$$

Assuming that a temperature $>85^{\circ} \mathrm{C}$ in a solar box can be established for at least $3 \mathrm{~h}$ per day in a respective climatic region, $\mathrm{t}$ is substituted by $3 \mathrm{~h}$. The volume of stored urine accumulating daily from one person is about $1.5 \mathrm{~L}$ [22]. The fraction $c_{L 0} / c_{L}(\mathrm{t})$ is substituted by 100 for a $99 \%$ removal of $F A N$ and $K_{L}$ by $0.00371 \mathrm{~m} \cdot \mathrm{h}^{-1}$ according to Table 1 . For these conditions, the area needed per capita for solar low-tech stripping of the stored urine resulting from Equation (8) is $0.62 \mathrm{~m}^{2}$. This results in a very shallow liquid layer with a depth of only 2.5 $\mathrm{mm}$. It is assumed that a great deal of the water will be in the gas phase under these conditions which can be looked at as beneficial for the subsequent solar drying process. Also for solar drying of urine, less than $1 \mathrm{~m}^{2}$ of land area is required per capita, as the total daily distillate yield of a solar still with built-in latent heat thermal energy storage was reported to be $4.6 \mathrm{~L} \cdot \mathrm{m}^{-2}$ [27].

During the experiments, an increase of the sulfuric acid volume was observed. This can be explained by the hygroscopic nature of sulfuric acid. In future investigations, other acids for $\mathrm{NH}_{3}$ absorption should be tested, e.g. phosphoric acid. Diammonium hydrogen phosphate is used as fertilizer for agriculture. After exhaustion, i.e. when nearly a neutral $\mathrm{pH}$ is reached, the absorber liquid represents a nitrogenous fertilizer. Also solid sorbents for ammonia such as H-type zeolites should be taken into consideration. They offer the advantage of easier handling compared to liquids.

\section{Conclusion}

At elevated temperatures $\left(74^{\circ} \mathrm{C}-80^{\circ} \mathrm{C}\right)$, ammonia can be recovered from stored human urine in a simple closed mass transfer apparatus without the requirement of devices which depend on electric power. The investigated low-tech ammonia stripping process can be realized as a solar process in solar boxes in regions with sufficient insolation because it is known from literature that water can be heated in solar boxes to more than $90^{\circ} \mathrm{C}$ for a couple of hours during the day. The area demand for the device of less than $1 \mathrm{~m}^{2}$ per capita is acceptable for rural areas. From the gas phase, the ammonia is absorbed in an acidic medium. Because of the high alkalinity of stored urine, the acid consumption by the pretreatment suggested in this study is considered lower than by preparing stored urine for solar evaporation by simple acidification. Solar experiments are required to evaluate the efficiency of the process and its limitations. Solar low-tech ammonia stripping represents a feasible pretreatment of stored urine prior to its enrichment by solar evaporation.

\section{References}

[1] Heinonen-Tanski, H. and van Wijk-Sijbesma, C. (2005) Human Excreta for Plant Production. Bioresource Technology, 96, 403-411. http://dx.doi.org/10.1016/j.biortech.2003.10.036

[2] Karak, T. and Bhattacharyya, P. (2011) Human Urine as a Source of Alternative Natural Fertilizer in Agriculture: A Flight of Fancy or an Achievable Reality. Resources Conservation and Recycling, 55, 400-408. http://dx.doi.org/10.1016/j.resconrec.2010.12.008 
[3] Makaya, J.M., Savadogo, A., Somda, M.K., Bour, J.-B., Barro, N. and Traoré, A.S. (2014) Quality of Human Urine Used as Fertilizer: Case of an Ecological Sanitation System in Ouagadougou Peri-Urban Areas-Burkina Faso. Journal of Environmental Protection, 5, 467-474. http://dx.doi.org/10.4236/jep.2014.56049

[4] Tidåker, P., Mattsson, B. and Jönsson, H. (2007) Environmental Impact of Wheat Production Using Human Urine and Mineral Fertilisers-A Scenario Study. Journal of Cleaner Production, 15, 52-62. http://dx.doi.org/10.1016/j.jclepro.2005.04.019

[5] Esrey, S.A., Andersson, I., Hillers, A. and Sawyer, R. (2001) Closing the Loop, Ecological Sanitation for Food Security. Publications on Water Resources No. 18.UNDP, SIDA, Mexico. http://www.ecosanres.org/pdf_files/closing-the-loop.pdf.

[6] Höglund, C., Ashbolt, N., Stenström, T.A. and Svensson, L. (2002) Viral Persistence in Source-Separated Human Urine. Advances in Environmental Research, 6, 265-275. http://dx.doi.org/10.1016/S1093-0191(01)00057-0

[7] Vinnerås, B., Nordin, A., Niwagaba, C. and Nyberg, K. (2008) Inactivation of Bacteria and Viruses in Human Urine Depending on Temperature and Dilution Rate. Water Research, 42, 4067-4074. http://dx.doi.org/10.1016/j.watres.2008.06.014

[8] Pronk, W. and Koné, D. (2010) Options for Urine Treatment in Developing Countries. Desalination, 251, 360-368.

[9] Pronk, W., Palmquist, H., Biebow, M. and Boller, M. (2006) Nanofiltration for the Separation of Pharmaceuticals from Nutrients in Source-Separated Urine. Water Research, 40, 1405-1412. http://dx.doi.org/10.1016/j.watres.2006.01.038

[10] Gulyas, H., Bruhn, P., Furmanska, M., Hartrampf, K., Kot, K., Lüttenberg, B., Mahmood, Z., Stelmaszewska, K. and Otterpohl, R. (2004) Freeze Concentration for Enrichment of Nutrients in Yellow Water from No-Mix Toilets. Water Science \& Technology, 50, 61-68.

[11] Antonini, S., Paris, S., Eichert, T. and Clemens, J. (2011) Nitrogen and Phosphorus Recovery from Human Urine by Struvite Precipitation and Air Stripping in Vietnam. CLEAN—Soil, Air, Water, 39, 1099-1104. http://dx.doi.org/10.1002/clen.201100036

[12] Morales, N., Boehler, M.A., Buettner, S., Liebi, C. and Siegrist, H. (2013) Recovery of N and P from Urine by Struvite Precipitation Followed by Combined Stripping with Digester Sludge Liquid at Full Scale. Water, 5, 1262-1278. http://dx.doi.org/10.3390/w5031262

[13] Ronteltap, M., Maurer, M., Hausherr, R. and Gujer, W. (2010) Struvite Precipitation from Urine-Influencing Factors on Particle Size. Water Research, 44, 2038-2046. http://dx.doi.org/10.1016/j.watres.2009.12.015

[14] Sendrowski, A. and Boyer, T.H. (2013) Phosphate Removal from Urine Using Hybrid Anion Exchange Resin. Desalination, 322, 104-112. http://dx.doi.org/10.1016/j.desal.2013.05.014

[15] Beler-Baykal, B., Bayram, S., Akkaymak, E. and Cinar, S. (2004) Removal of Ammonium from Human Urine through Ion Exchange with Clinoptilolite and Its Recovery for Further Reuse. Water Science \& Technology, 50, 149-156.

[16] Ganrot, Z., Dave, G. and Nilssen, E. (2007) Recovery of N and P from Human Urine by Freezing, Struvite Precipitation and Adsorption to Zeolite and Active Carbon. Bioresource Technology, 98, 3112-3121. http://dx.doi.org/10.1016/j.biortech.2006.10.038

[17] Başakçilardan-Kabakci, S., İpekoğlu, A.N. and Talinli, I. (2007) Recovery of Ammonia from Human Urine by Stripping and Absorption. Environmental Engineering Science, 24, 615-624. http://dx.doi.org/10.1089/ees.2006.0412

[18] Behrendt, J., Arevalo, E., Gulyas, H., Niederste-Hollenberg, J., Niemiec, A., Zhou, J. and Otterpohl, R. (2002) Production of Value-Added Products from Separately Collected Urine. Water Science \& Technology, 46, 341-346.

[19] Siegrist, H., Laureni, M. and Udert, K.M. (2013) Transfer into the Gas Phase: Ammonia Stripping. In: Larsen, T.A., Udert, K.M. and Lienert, J., Eds., Source Separation and Decentralization for Wastewater Management, IWA Publishing, London, 337-350.

[20] Antonini, S., Nguyen, P.T., Arnold, U., Eichert, T. and Clemens, J. (2012) Solar Thermal Evaporation of Human Urine for Nitrogen and Phosphorus Recovery in Vietnam. Science of the Total Environment, 414, 592-599. http://dx.doi.org/10.1016/j.scitotenv.2011.11.055

[21] Udert, K.M. and Wächter, M. (2012) Complete Nutrient Recovery from Source-Separated Urine by Nitrification and Distillation. Water Research, 46, 453-464. http://dx.doi.org/10.1016/j.watres.2011.11.020

[22] Meinzinger, F. and Oldenburg, M. (2009) Characteristics of Source-Separated Household Wastewater Flows: A Statistical Assessment. Water Science \& Technology, 59, 1785-1791. http://dx.doi.org/10.2166/wst.2009.185

[23] Emerson, K., Russo, R.C., Lund, R.E. and Thurston, R.V. (1975) Aqueous Ammonia Equilibrium Calculations: Effect of $\mathrm{pH}$ and Temperature. Journal of the Fisheries Research Board of Canada, 32, 2379-2383. http://dx.doi.org/10.1139/f75-274

[24] Khoo, K.H., Culberson, C.H. and Bates, R.G. (1977) Thermodynamics of the Dissociation of Ammonium Ion in Seawater from $5^{\circ} \mathrm{C}$ to $40^{\circ} \mathrm{C}$. Journal of Solution Chemistry, 6, 281-290. http://dx.doi.org/10.1007/BF00645459 
[25] Ali, M. (2000) Design and Testing of Sudanese Solar Box Cooker. Renewable Energy, 21, 573-581. http://dx.doi.org/10.1016/S0960-1481(00)00089-6

[26] Rikoto, I.I. and Garba, I. (2013) Comparative Analysis on Solar Cooking Using Box Type Solar Cooker with Finned Cooking Pot. International Journal of Modern Engineering Research, 3, 1290-1294.

[27] Radwhan, A.M. (2004) Transient Performance of a Stepped Solar Still with Built-In Latent Heat Thermal Energy Storage. Desalination, 171, 61-76. http://dx.doi.org/10.1016/j.desa1.2003.12.010 
Scientific Research Publishing (SCIRP) is one of the largest Open Access journal publishers. It is currently publishing more than 200 open access, online, peer-reviewed journals covering a wide range of academic disciplines. SCIRP serves the worldwide academic communities and contributes to the progress and application of science with its publication.

Other selected journals from SCIRP are listed as below. Submit your manuscript to us via either submit@scirp.org or Online Submission Portal.
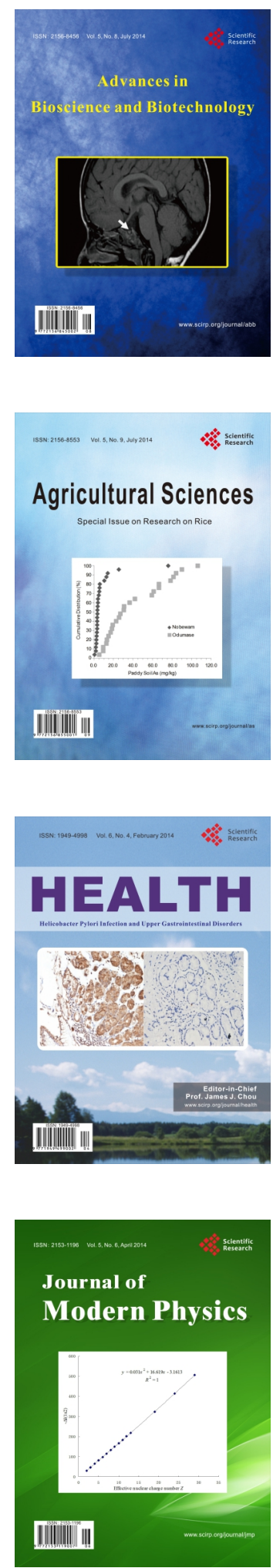
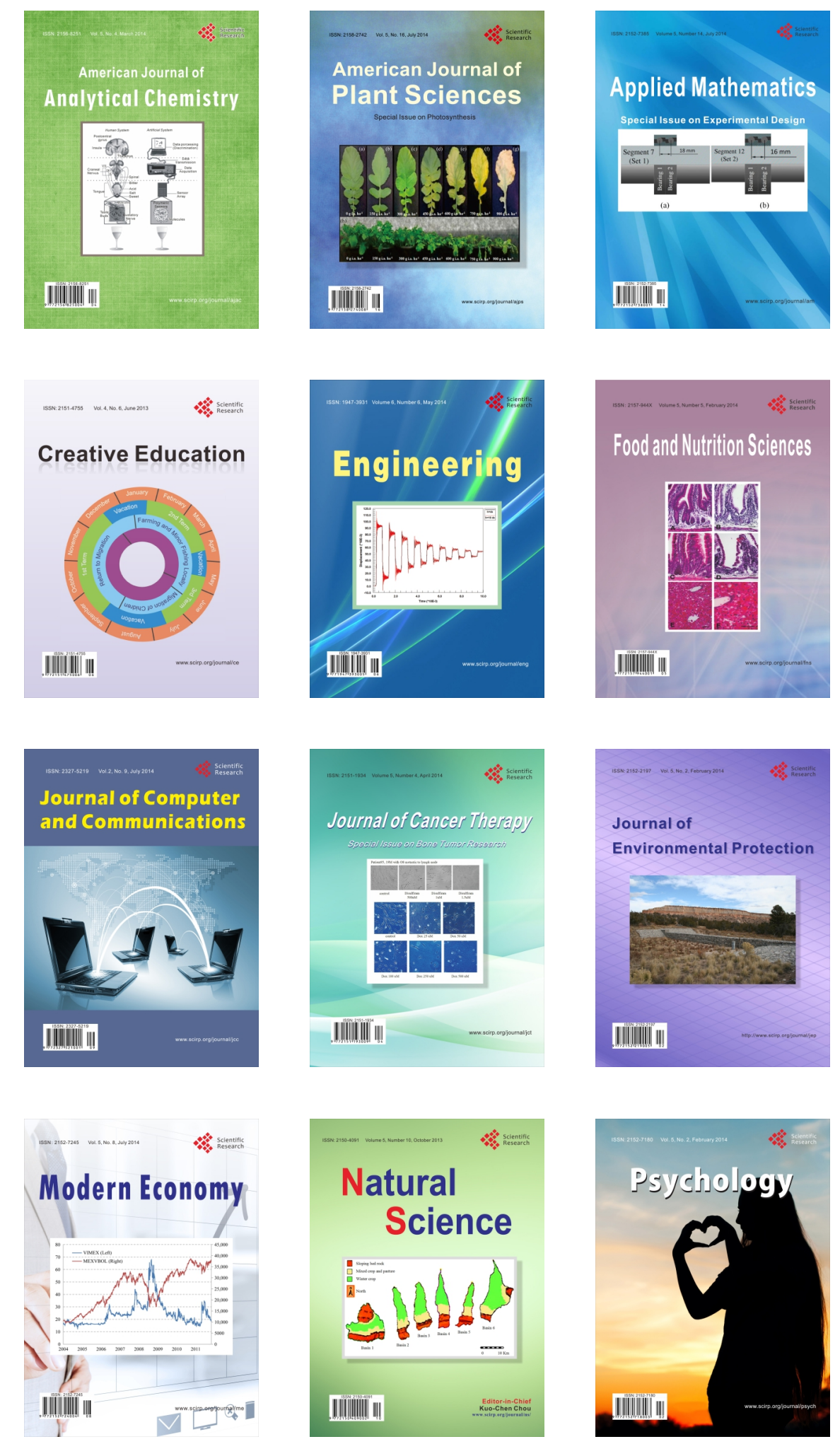